\title{
A new species of Asphondylia (Diptera: Cecidomyiidae) and a key to separate species of the genus associated with Asteraceae from Neotropical region
}

\author{
Maria Virginia Urso-Guimarães ${ }^{1,2,3}$ \\ 1 Universidade Federal de São Carlos (UFSCAR), Centro de Ciências Humanas e Biológicas (CCHB), Departamento de Biologia (DBio), \\ Laboratório de Sistemática de Diptera. Sorocaba, SP, Brasil. \\ 2 Universidade de São Paulo (USP), Museu de Zoologia (MZUSP). São Paulo, SP, Brasil. \\ 3 ORCID: 0000-0003-3657-9379. E-mail: mvirginiaurso@gmail.com
}

\begin{abstract}
A new species, Asphondylia cipo sp. nov. (Diptera: Cecidomyiidae) causing stem and petiole galls on Lessingianthus warmingianus (Baker) H. Rob. (Asteraceae) is described and illustrated from Serra do Cipó, Minas Gerais State, Brazil. A key is provided to separate species of this genus associated with host plants in the Asteraceae family from the Neotropical region.
\end{abstract}

Key-Words. Asphondyliini; Insect-plant association; Morphology; Taxonomy.

\section{INTRODUCTION}

Asphondylia Loew, 1850 belongs to the tribe Asphondyliini of the subfamily Cecidomyiinae (Diptera: Cecidomyiidae). The genus is cosmopolitan with 299 species described to date, of which about 100 species occur in the Neotropical region and 21 in Brazil (Gagné \& Jaschhof, 2017; Flor \& Maia, 2017). Asphondylia species have been recorded on 66 plant families in the world, being most frequently found on Asteraceae, Fabaceae, and Chenopodiaceae (Gagné \& Jaschhof, 2017). So far, 19 species of Asphondylia have been associated with Asteraceae species in the Neotropical region, mostly shrubs and herbs.

A new species, Asphondylia cipo sp. nov., is described here. The specimens were reared from stem and petiole galls of Lessingianthus warmingianus (Baker) H. Rob. (Asteraceae) sampled from the Serra do Cipó, Minas Gerais State, Brazil. Lessingianthus $\mathrm{H}$. Rob. is a Neotropical genus of the tribe Vernonieae, which includes species that had previously been placed in Vernonia Schreber (Antar \& Loeuille, 2015). This genus has more than 135 species distributed in South America, of which 115 occur in Brazil, with 85 being endemic (Dematteis \& Almeida, 2015). Lessingianthus warmingianus is a perennial subshrub, native to Brazil and endemic to the Cerrado and rupestrian fields in Goiás and Minas Gerais (Dematteis \& Almeida, 2015). Previously thirteen morphotypes of insect galls were described to Lessingianthus species, all in Cadeia do Espinhaço, MG. Twelve of the morphotypes were induced by undescribed species of cecidomyiids in six species of Lessingianthus (Lessingianthus coriaceus (Less.) H. Rob., Lessingianthus elegans (Gardner) $\mathrm{H}$. Rob., Lessingianthus hoveaefolius (Gardner) $\mathrm{H}$. Rob., Lessingianthus linearifolius (Less.) H. Rob., Lessingianthus pychnostachius (DC.) H. Rob., and Lessingianthus tomentellus (Mart.) H. Rob); and one on stem of Lessingianthus warmingianus induced by an undescribed species of coleopterous (Carneiro et al., 2009; Maia, 2012; Coelho et al., 2013).

Previously no Asphondylia species have been described from Lessingianthus neither to Neotropics nor to other biogeographical region in the world. Here the new species is described, named Asphondylia cipo sp. nov. and compared to 19 congeners associated with Asteraceae in the Neotropical region. A key is provided to separate these species.

\section{MATERIAL AND METHODS}

Branches of Lessingianthus warmingianus (Baker) H. Rob. (Asteraceae) with galls of Asphondylia cipo sp. nov. were collected from rupestrian field vegetation on the Pedra do Elefante trail in Serra do Cipó, Municipality of Santana do Riacho, Minas Gerais State, Southeastern Brazil (S19 $17.468^{\prime \prime} ; \mathrm{W} 43^{\circ} 32.564^{\prime \prime}, 1,237 \mathrm{~m}$ altitude) on 14.xi.2002. Galls were transferred to individual plastic bags for adult rearing. Some galls were dissected under a stereomicroscope to obtain immature specimens. All material was conserved 
in $80 \%$ alcohol for slide mounting, following the method outlined in Gagné (1994), as well as the terminology of morphological characters. The type specimens of the new species were deposited in the Museu de Zoologia da Universidade de São Paulo (MZUSP).

Specimens of Asphondylia anaceliae Möhn, Asphondylia serrata Maia, Asphondylia glomeratae Gagné, Asphondylia gochnatiae Maia, and Asphondylia cipo sp. nov. were examined for comparison. The characters of other species were taken from original descriptions or revisions (Gagné, 1994; Gagné et al., 2001; Kieffer \& Herbst, 1905; Möhn, 1959, 1960, 1973; Rübsaamen, 1908; Wünsch, 1979).

\section{RESULTS AND DISCUSSION}

\section{Taxonomy}

Genus Asphondylia Loew 1850: 21, 37, as subg. of Cecidomyia.

Type species: Asphondylia sarothamni Loew (subs. des. Karsch, 1877: 15).

For the diagnosis of Asphondylia see Gagné (1994) and Flor \& Maia (2017).

\section{Asphondylia cipo sp. nov. \\ (Figures 1-6)}

Description: Adult: Thorax brown, abdomen orange. Body length, male 3.5-5.2 $\mathrm{mm}(\mathrm{n}=13)$, female 4.2-6.2 mm $(n=10)$. Head (Fig. 1A): Eyes black, holoptic, facets octagonal, closely adjacent, with long setae. Antenna typical of Asphondylia (2+12 cylindrical flagellomeres; male 2.2-3.1 mm; female 2.2-2.8 mm; scape elongated, male $0.17 \mathrm{~mm}$, female $0.18 \mathrm{~mm}$; and distally enlarged; pedicel round, male $0.06 \mathrm{~mm}$, female $0.07 \mathrm{~mm}$; sinuous circumfila in male (Fig. 1B), and simple in female (Fig. 1C); $9^{\text {th }}-12^{\text {th }}$ male flagellomere with length approximately equal (Fig. 1D); $9^{\text {th }}-12^{\text {th }}$ female flagellomeres progressively shorter (Fig. 1E). Frontoclypeus with about 20-24 setae ( $n=16$, males and females), labrum elongated with 2-3 pairs of ventral setae. Hypopharynx triangular with short lateral setulae, labella round-convex, each with 6-7 setae; palpus three-segmented, shape and setae as in figure 1F. Thorax: Dark brown, antepronotal lobe bare, scutum with dorsocentral rows of setae and lateral setae present, anepistemum with $50-52$ setae in male $(n=13)$ and 52-54 setae in female $(n=10)$; katepistemum bare; anepimeron with three rows with $56-58$ setae in male $(n=13)$ and $60-62$ setae in female $(n=10)$, mediotergite bare, laterotergite with eight trichoid sensilla near halter base. Legs: First tarsomere of each leg with an apicoven-
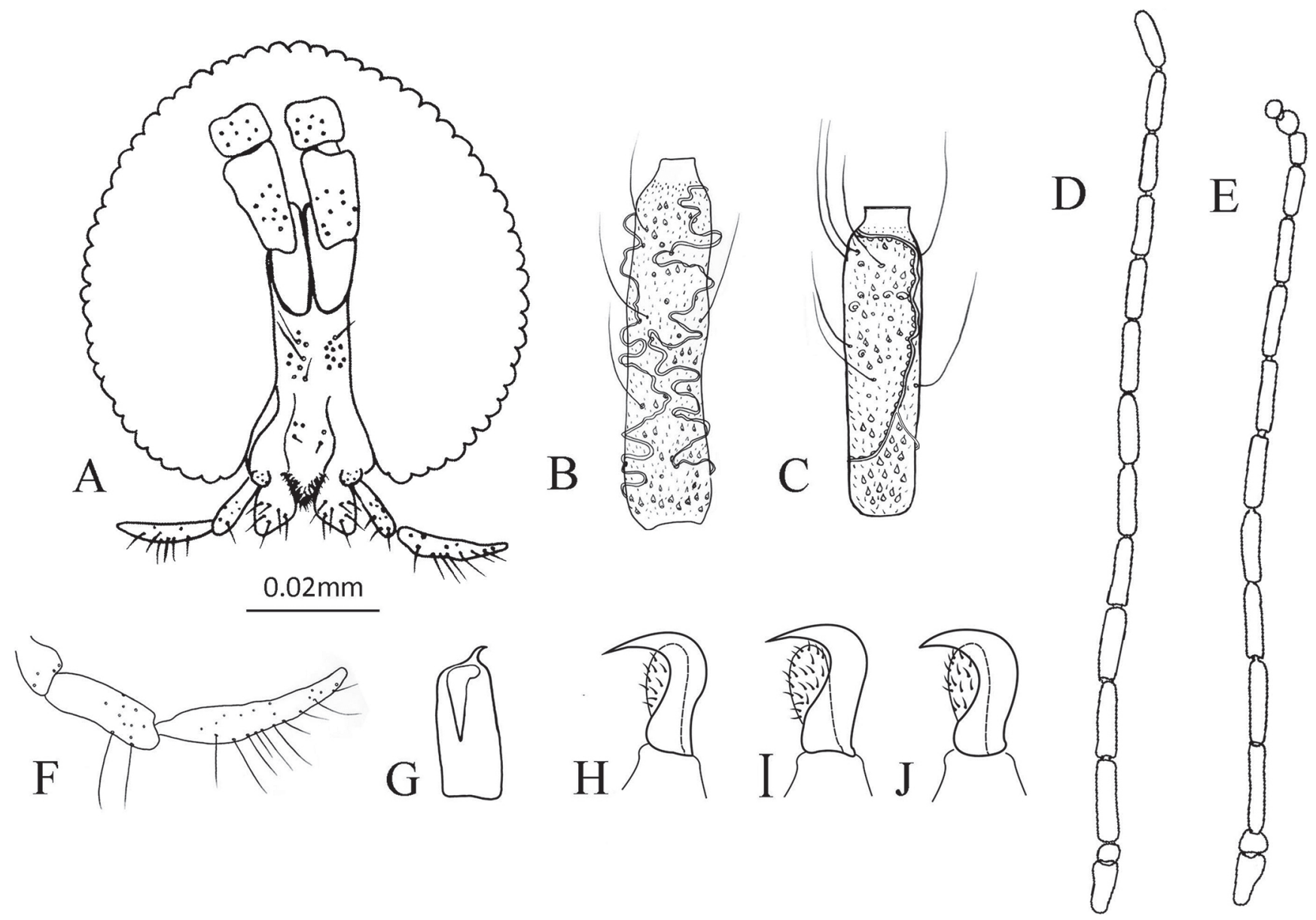

Figure 1. Asphondylia cipo sp. nov. (A) Head in frontal view; (B) Male $3^{\text {rd }}$ flagellomere; (C) Female $3^{\text {rd }}$ flagellomere; (D) Male $9^{\text {th }}-12^{\text {th }}$ flagellomeres; (E) Female $9^{\text {th }}-12^{\text {th }}$ flagellomeres; (F) Palpus; (G) First tarsomere with apicoventral spur; (H) Foretarsal claw and empodium; (I) Midtarsal claw and empodium; (J) Foretarsal claw and empodium. 


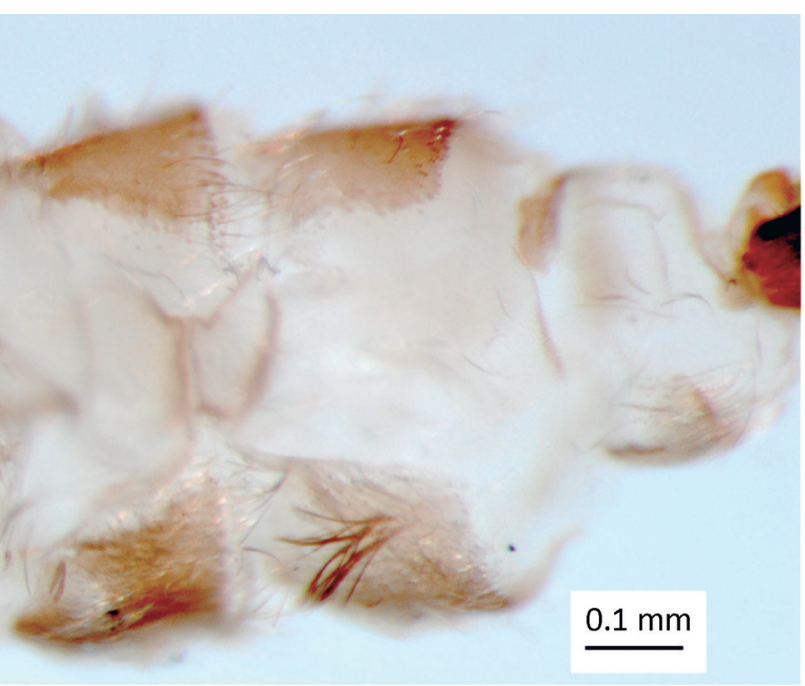

A

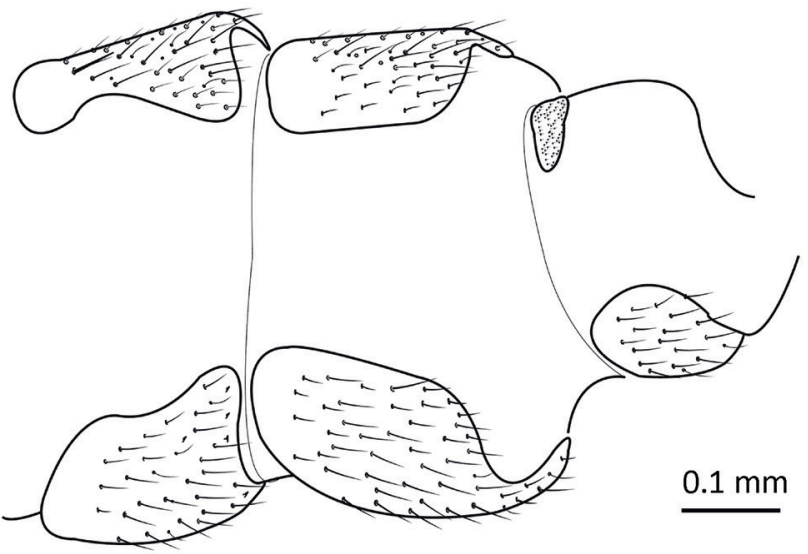

B

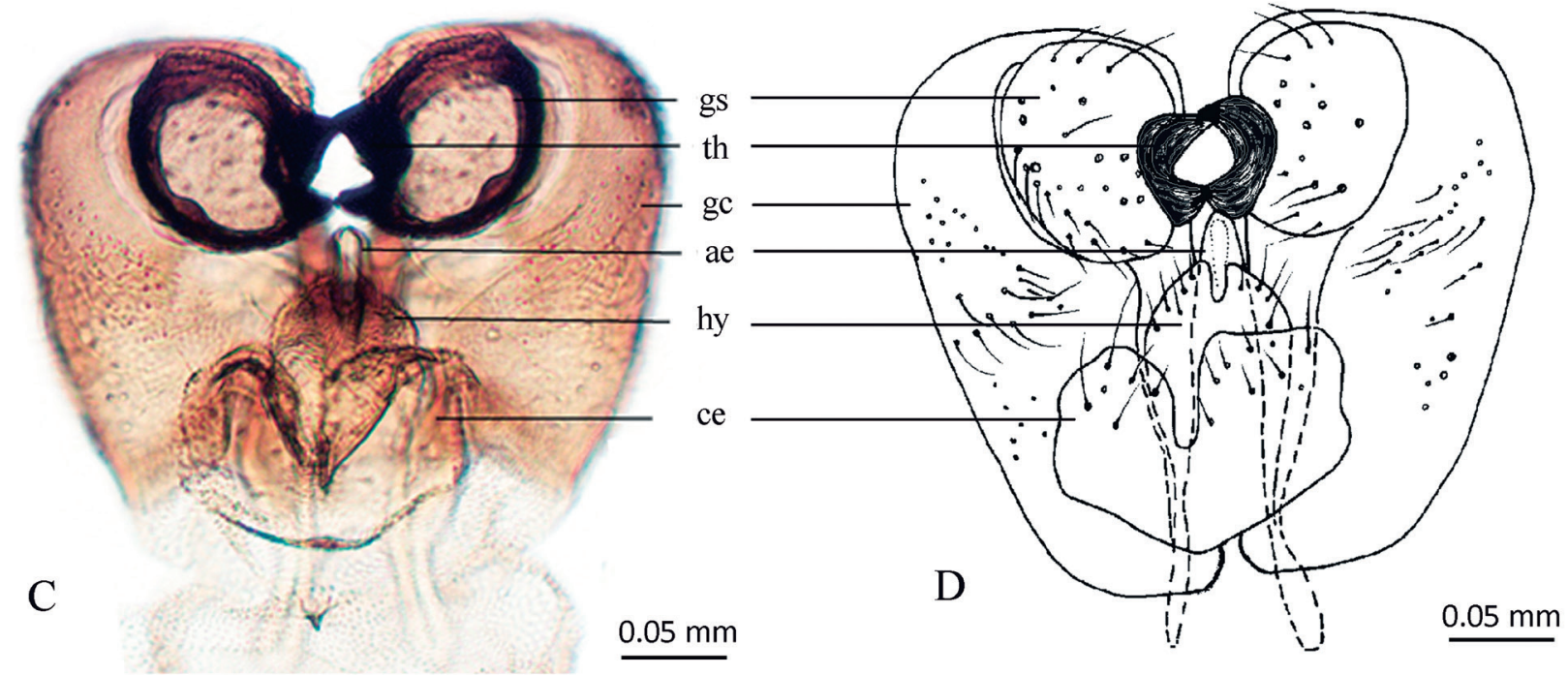

Figure 2. Asphondylia cipo sp. nov. (A, B) Male abdomen in lateral view; $(C, D)$ Male terminalia in dorsal view. Abbreviations: $c e=$ cercus, gc $=g o n o c o x i t e, g s=$ gonostyle, hy = hypoproct, s7 = sternite 7 , th $=$ teeth of gonostyle.
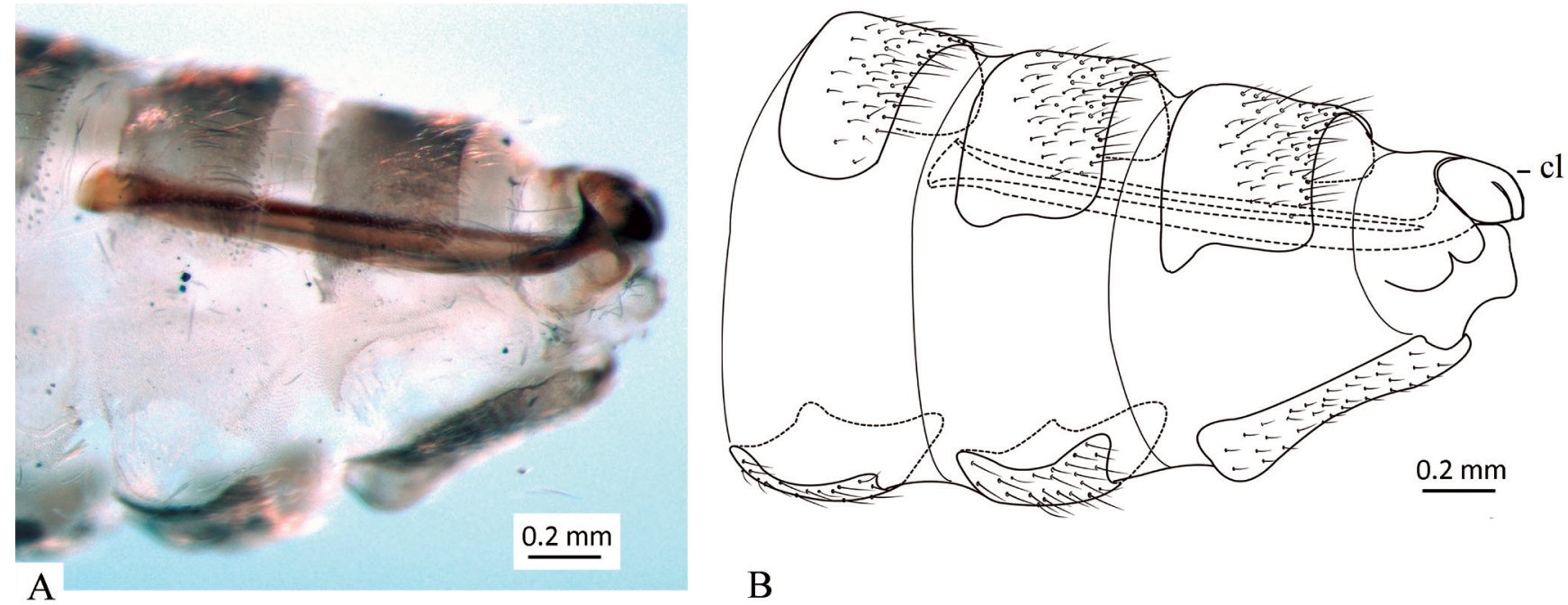

Figure 3. Asphondylia cipo sp. nov. (A, B) Abdominal segments 7 and 8 and ovipositor in ventro-lateral view. Abbreviation: $c l=$ cercilike lobes. 

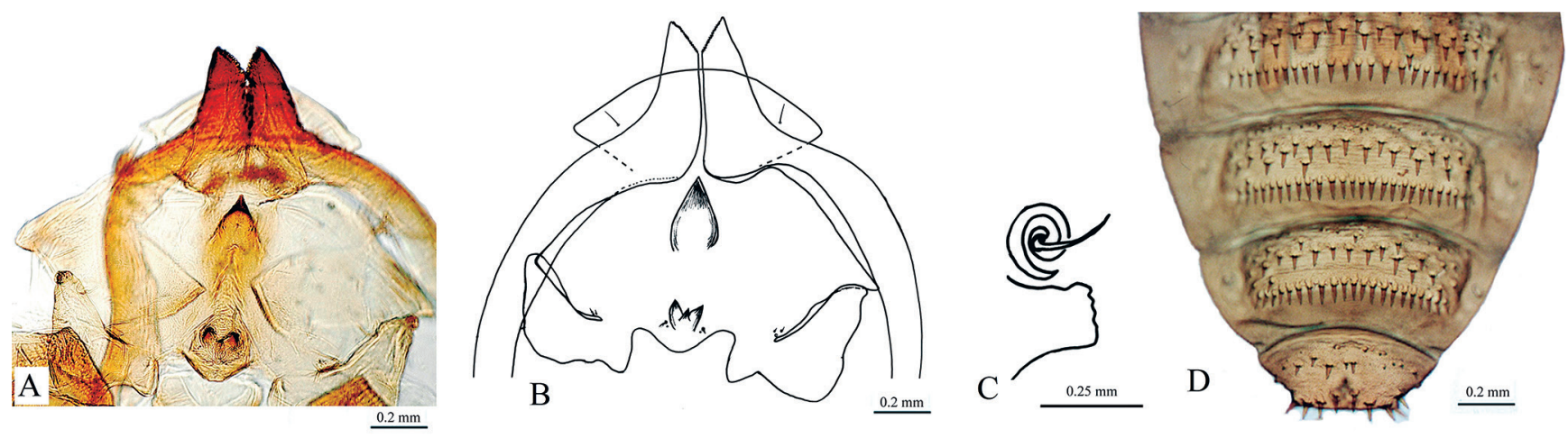

Figure 4. Asphondylia cipo sp. nov. (A, B) Pupa in ventral view; (C) Posterior region of pupa in dorsal view; (D) Prothoracic spiracle and the accessory structure.
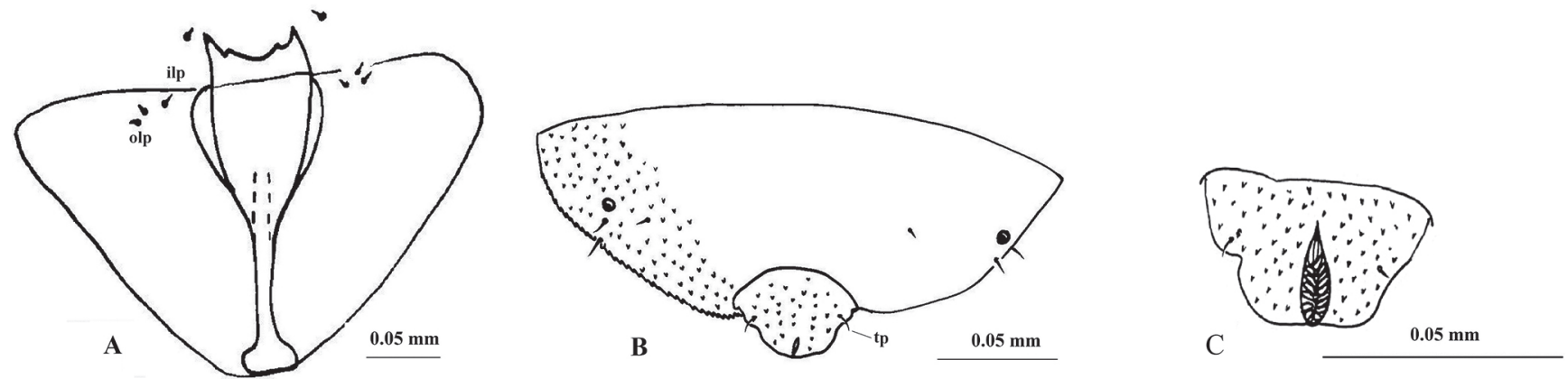

Figure 5. Asphondylia cipo sp. nov. (A) Larval spatula and lateral papillae in ventral view; (B) Larval eighth and terminal segment with terminal papillae, in dorsal view; (C) Larval terminal segment with elongated cells around anus, in terminal-dorsal view. Abbreviations: ilp = inner lateral papillae; olp = outer lateral papillae; tp $=$ terminal papillae.

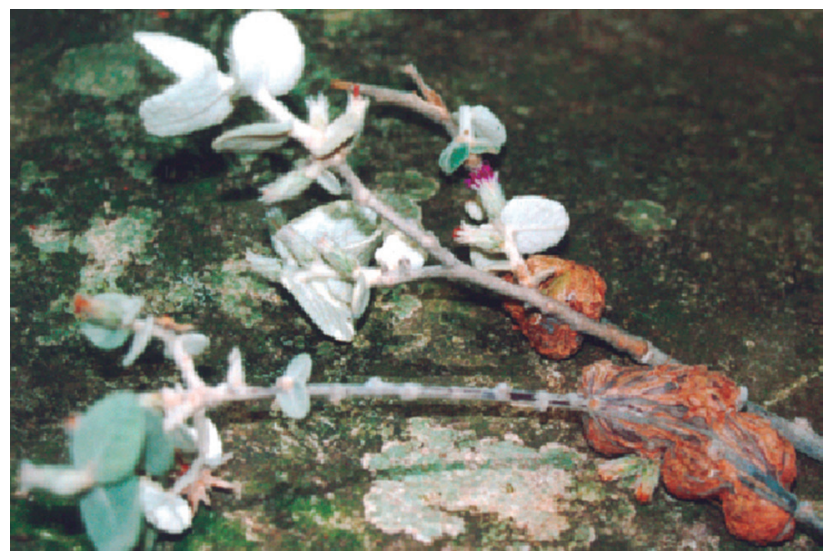

Figure 6. Stem and petiole galls induced by Asphondylia cipo sp. nov. in Lessingianthus warmingianus (Baker) H. Rob. (Asteraceae). Arrow indicates a petiole gall.

tral spur 0.03-0.04 mm long (Fig. 1G); tarsal claws all equal in size and shape, as long as empodia (Figs. $1 \mathrm{H}, 1 \mathrm{l}, 1 \mathrm{~J}$ ). Wing length (from arculus to apex): males: $3.5-4.4 \mathrm{~mm}$ ( $n=13)$, females: 4.1-4.9 mm $(n=10)$, venation typical of Asphondylia.

Abdomen: Male: Tergites and sternites 1-7: rectangular and completely sclerotized; a row of strong setae along the posterior margin of tergites, setae scattered elsewhere, scales absent. Tergite 8 a narrow sclerotized band with a row of strong setae along the posterior margin. Sternite 8 ovoid, well sclerotized with several scattered setae concentrated caudally. Trichoid sensilla absent in tergites and sternites (Figs. 2A, 2B). Male terminalia (Figs. 2C, 2D): Gonocoxite wide and setose, 0.2-0.23 mm length ( $\mathrm{n}=13$ ) and 1.3-1.5 times as long as wide; gonostylus short ovoid, setose, $0.09 \mathrm{~mm}$ long $(n=13)$ and as long as wide, two-toothed; cercus round, fused at base, lobed at apex; hypoproct bilobed; aedeagus triangular, tapering gradually towards the apex and pointed apically, sclerotized.

Abdomen: Female (Figs. 3A, B): tergites 1-7 as in male. Sternites 2-6 as in male, sternite 7 ovoid, $0.7 \mathrm{~mm}$ long, with scattered setae; 1.5 of the length of sternite 6 . Sternite 8 non-sclerotized. Trichoid sensilla absent in tergites and sternites. Ovipositor: protractible part $1.6 \mathrm{~mm}$ length, 2.3 times longer than sternite 7.

Pupa (Figs. 4A-D): Brown, abdominal integument rough, with microspines dorsally, and round sclerotized plates ventrally in abdomen surface. Body length, 4.3-6.4 mm, 1.8-2.0 mm maximum width $(\mathrm{n}=32)$. Head (Figs. 4A, 4B). Antennal horns, $0.02 \mathrm{~mm}$, well developed, triangular, inner margin finely serrate, outer margin smooth. Upper frontal horn simple, $0.11 \mathrm{~mm}$ length, lower frontal horn trilobed, $0.04 \mathrm{~mm}$ length each; presence of two pairs of lower facial papillae (one setose and the other bare), three pairs of lateral papillae (one setose and two bare); cephalic setae short, $0.07 \mathrm{~mm}$ length. Thorax: Prothoracic spiracle short, $0.12 \mathrm{~mm}$ length, setiform with an accessory structure in spiral format (Fig. 4C). Wing reaching third abdominal segment and legs reaching fifth abdominal segment. Abdominal tergites 2-8 with two rows of strong spines in caudal area and small spines 
scattered in proximal area. Terminal segment with one row of hooked spines (Fig. 4D). Pupation in gall.

Larva 3rd instar: Light cream. Body, $3.1 \mathrm{~mm}$ length, 1.6 maximum width $(n=1)$. Integument sclerotized, cephalic setae, $0.01 \mathrm{~mm}$ length. Thorax: Area around prothoracic spatula pigmented, spatula $0.3 \mathrm{~mm}$ length, four teeth anteriorly, middle tooth smaller than lateral teeth, with narrow shaft; one pair of setose inner lateral papillae and two pairs of setose outer lateral papillae (Fig. 5A). Abdomen: Segments 1-8 covered by round plates with microspines dorsally and ventrally, spiracles short and sclerotized; terminal segment (Fig. 5B), $0.03 \mathrm{~mm}$ length, 0.07 maximum width, round with a pair of short setose papillae; anus dorsal in cleft, flanked by elongated cells (Fig. 5C).

Etymology: The specific name "cipo" is in apposition, referring to the type locality, Serra do Cipó.

Gall and biology (Fig. 6): Globoid stem and petiole swelling on Lessingianthus warmingianus (Baker) $\mathrm{H}$. Rob. (Asteraceae). Galls are bare, monothalamous, unilocular even when closely approximated to one another. The interior of larval chamber is lined with a fungal mycelium, as described for $A$. glomeratae and $A$. moehni in Gagné et al. (2001). Pupation in gall. The adults emerged through an escape hole dug with the antennal horns of the pupa.

Holotype: Male: Brazil, Minas Gerais: Santana do Riacho, Pedra do Elefante trail in Serra do Cipó (S19 17.468"; W43 ${ }^{\circ} 32.564^{\prime \prime}, 1,237 \mathrm{~m}$ altitude), collected 14.xi.2002; emerged 20.xi.2002, collected and reared by M.V. Urso-Guimarães from stem and petiole swellings on Lessingianthus warmingianus (Baker) H. Rob. (Asteraceae). Deposited in slides as mounted specimen at the MZSP.

Paratypes: 57 specimens, same data as holotype, except for: 1 male, 1 female, 1 pupal exuviae, 1 larva; in alcohol: same collect date of holotype, except for: 1 male, $2 \mathrm{fe}$ males, 2 pupae, 4 exuviae emerged in 18.xi.2002; 1 male, 1 female, 10 pupae, 2 exuviae emerged in 19.xi.2002; 4 males, 4 females, 1 pupa, 8 exuviae, 2 larvae emerged in 21.xi.2002; 1 male, 1 exuvia emerged in 25.xi.2002;
1 male, 1 exuvia emerged in 26.xi.2002; and 3 males, 2 females, 2 exuviae emerged in 03.xii.2002 (deposited in MZSP).

Remarks: Asphondylia cipo sp. nov. can be easily differentiated from any other species of the genus by the following set of characters: the great body length; needle part of ovipositor $1.6 \mathrm{~mm}$ length, 2.3 times longer than sternite 7; upper frontal horn simple, lower frontal horn trilobed; prothoracic spiracle setiform with an accessory structure in spiral format; four-toothed prothoracic spatula of larva, the inner pair tiny and widely separated; one pair of discrete terminal papillae; galls on stem and petiole of Lessingianthus warmingianus.

Of the 16 species Asphondylia inducing galls on Asteraceae whose larvae are known, only $A$. ajallai, A. serrata, A. ulei, A. zacatechichi, and A. cipo sp. nov. have spatula with inner teeth much less than $1 / 2$ the size of the outer with the inner incision flat and wide (Fig. 7F), however, the distance between the inner teeth is much larger in $A$. cipo sp. nov. than in the other known species; from these, only $A$. serrata and $A$. cipo sp. nov. share one inner and two outer lateral papillae, $A$. ajallai and $A$. ulei have two inner and two outer lateral papillae, and A. zacatechichi has 3inner and 2 outer lateral papillae. Asphondylia cipo sp. nov. differ of $A$. serrata by the shape of antennal horn, triangular in the former, rectangular in the later in pupa; and in females, the needle part of ovipositor is 2.3 times longer than sternite 7 in the former and 1.87 in the later. The morphological evidence discussed above indicates that this species is distinct from all other species of Asphondylia inducing galls on Asteraceae described previously.

\section{Identification key to the species of Asphondylia associated with Asteraceae in the Neotropical region}

The male and female characters of Asphondylia are near all similar among the species, that's why most of the characters used in the key are from pupa, larva, host plants, and galls. The adults of $A$. ulei Rübsaamen, Asphondylia zacatechichi Möhn, and Asphondylia zexmeniae Möhn; the pupa of A. ajallai Möhn, $A$. corbulae Möhn, A. herculesi Möhn; and the larvae of $A$. tithoniae Möhn are
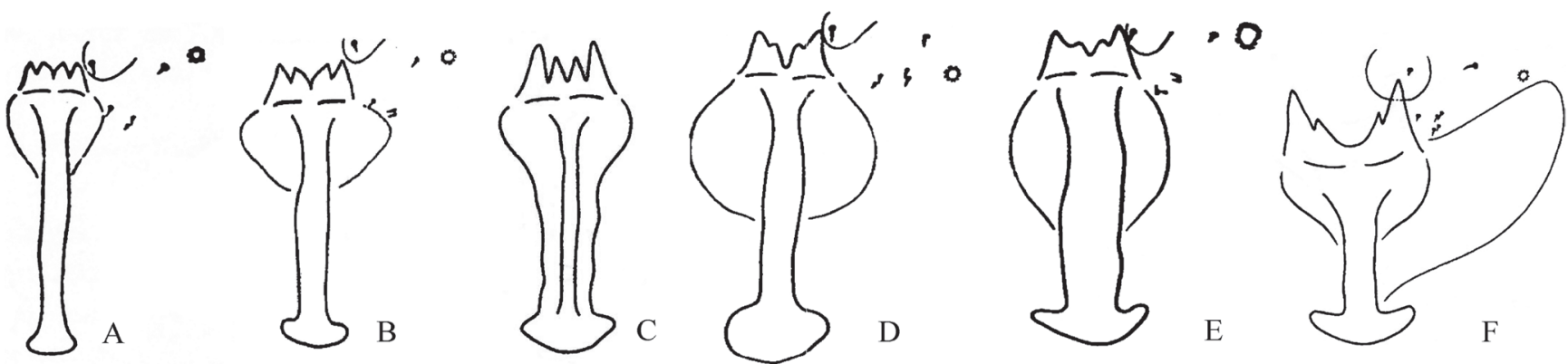

Figure 7. Relative size of inner and outer teeth of the larval prothoracic spatula of Asphondylia species associated with Asteraceae in Neotropical region. (A, B) Inner teeth approximately equal in size as outer, (A) Asphondylia salvadorensis, (B) A. corbulae; (C, D, E) Inner teeth reach at least $1 / 2$ of outer teeth, (C) Inner incision absent, A. moheni, (D) Inner incision deep and narrow, A. caleae, (E) Inner incision shallow, A. trixidis; (F) Inner teeth of spatula minute, inner incision flat and wide, $A$. ulei. Figures 7A, 7D, 7E modified from Möhn (1959), 7B from Möhn (1960); 7C, 7F from Möhn (1973). 

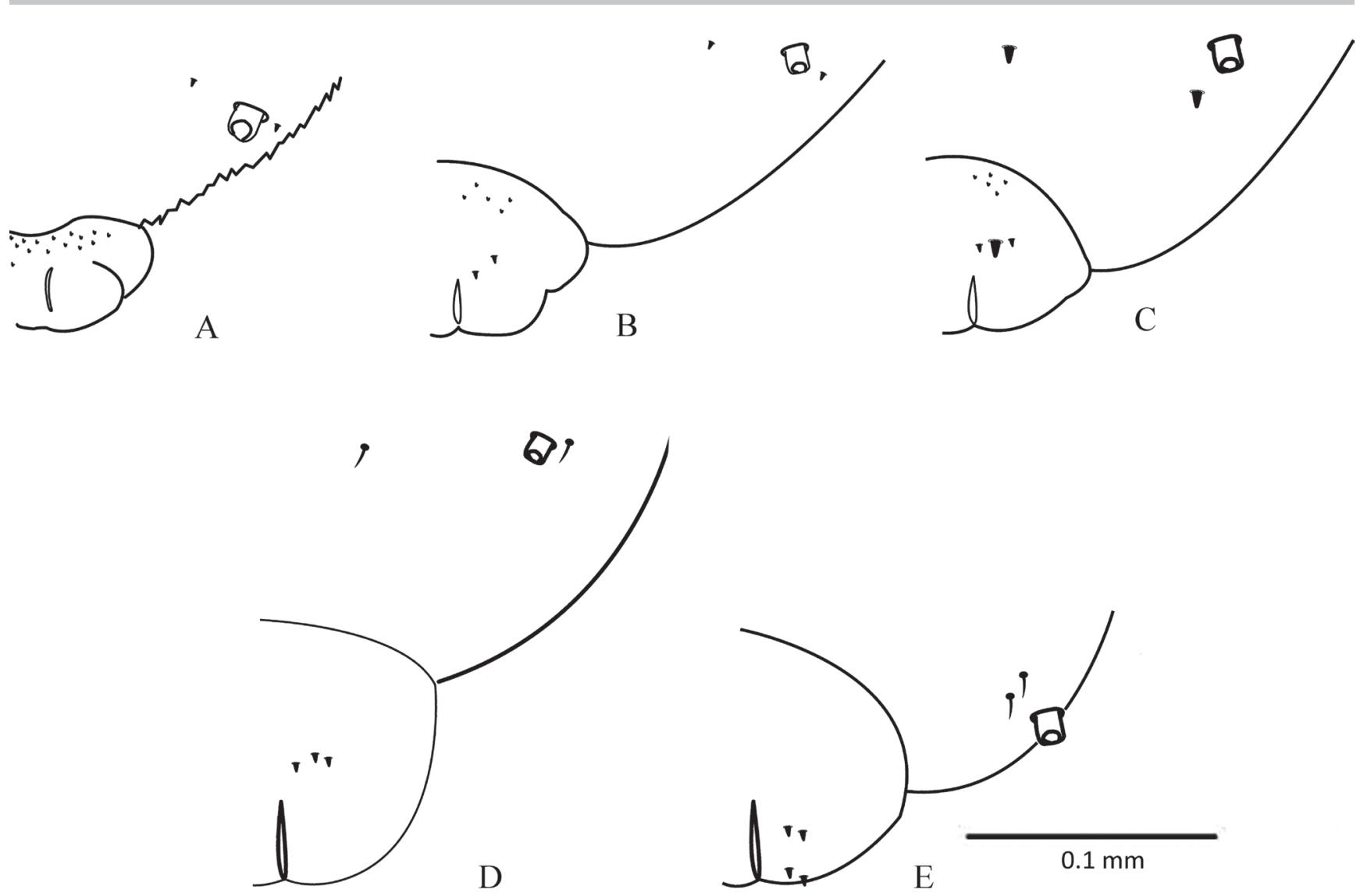

Figure 8. Terminal segment of Asphondylia species. (A) Asphondylia glomerata, (B) A. ajjalai, (C) A. salvadorensis, (D) A. ulei, (E) A. gochnatiae, (F) A. serrata. Figure 8A modified from Gagné et al. (2001), 8B, 8C from Möhn (1959), 8D from Möhn (1973), 8E from Maia (2004).

unknown; A. duplicornis Wünsch is known only from female and pupa. The original description of $A$. baccharis Kieffer \& Herbst is very unspecific and the type specimens have been lost. Of the twenty species of Asphondylia associated with Asteraceae in the Neotropical region, only four were not included in this key: $A$. duplicornis (Distrib. Colombia: Magdalena Prov., Canaverales) and A. tithoniae (Distrib. El Salvador: La Libertad, E Sitio del Nino) because the larvae are unknown; $A$. baccharis (Distrib. Chile: vic. San Vicente) because the type specimens are lost. Asphondylia hieronymi (Weyenbergh) (Distrib. Argentina) could be included in the Asphondylia species grouped under the couplet 5', which larval spatula was described with four teeth, the inner much less than $1 / 2$ of outer, with inner incision flat and wide, but the required information to the next steps of the key is unavailable in the original description and the type specimens are referred as lost in Gagné \& Jaschhof (2017).

1. Larval spatula with four teeth, outer and inner pairs of spatula teeth approximately equal in size (Figs. 7A, 7B).

- Larval spatula with four teeth, outer and inner pairs of spatula teeth unequal in size (Figs. 7C, 7D, 7E, 7F)

2. Larva with two inner and two outer lateral papillae; terminal segment of larva with one (Fig. 8A) or four terminal papillae (Fig. 8E) ...

- L Larva with one inner and two outer lateral papillae; terminal segment of larva with three papillae, two setose and one corniform (Fig. 8C)

3. Larva with terminal segment with one pair of setiform terminal papillae barely visible among microspines (Fig. 8A); vein swelling on leaves of Mikania glomerata Sprengl. (Distrib. Brazil: Rio de Janeiro, Poço das Antas; Minas Gerais, Lavras).

.A. glomeratae Gagné Larva with terminal segment with four terminal papillae, three setiform and one corniform (Fig. 8E); hairy galls on leaf and petiole on Moquiniastrum polymorphum (Less.) G. Sancho (Distrib. Brazil: Minas Gerais, Luz)... A. gochnatiae Maia

4. Larva with the inner teeth of spatula slightly shorter than outer (Fig. 7B); bud galls on Eupatorium sp.; Chromolaena odorata, Fleischmannia microstemon (Distrib. El Salvador: Ahuachapan, NW Las Chinamas; Guadeloupe FWI, Trinidad) A. corbulae Möhn Larva with the inner teeth of spatula approximately equal in size to outer (Fig. 8A); bud galls in Hymenostephium cordatum (Distrib. El Salvador: San Salvador) ..A. salvadorensis Möhn

5. Larva with the inner teeth of spatula reach at least $\frac{1}{2}$ of outer teeth, inner incision absent (Fig. 7C) or, if present, deep and narrow (Fig. 7D) .................... 6

- Larva with the inner teeth of spatula minute, with much less than $1 \frac{1}{2}$ of outer teeth, inner incision present, flat and wide (Fig. 7E) 12

6. Larva with the inner teeth of spatula closer without inner incision (Fig. 7C); stem swellings galls on Mikania glomerata Sprengl. (Distrib. Brazil: Rio Grande do Sul, Rio de Janeiro) A. moehni Skuharavá Larva with the inner teeth of spatula with inner incision deep and narrow (Fig. 7D)

7. Larva with three inner and two outer lateral papillae; bud and axil leaf galls on Melanthera nivea (L.) Small (Distrib. El Salvador: San Miguel, N El Delirio). 
8. Larva with three pairs of terminal papillae, two setose and one corniform; induce fruit galls on Lepidaploa canescens (Kunth) H. Rob. (Distrib. El Salvador: Chalatenango, SE La Palma) A. herculesi Möhn

- Larva with one or two pairs of terminal papillae . .9

9. Larva with one pair of setose terminal papillae; galls on bud on flowers of Zexmenia frutescens (Mill.) S.F. Blake (Distrib. El Salvador: San Salvador) A. zexmeniae Möhn

- Larva with two pairs of terminal papillae .... 10

10. Larva with two pairs of terminal papillae, one setose and the other corniform; on stem and leaf vein on Bidens squarrosa Less. and B. refracta Brandegee (Distr. El Salvador: La Libertad, Cumbre, Hacienda Chilata) ..A. anaceliae Möhn

- Larva with two pairs of terminal papillae, both setose ... 11

11. Larva with inner incision of spatula very deep (Fig. 6D); bud galls on flowers of Calea integrifolia (DC.) Hemsl. (Distr. El Salvador: San Salvador, Picacho)..... A. caleae Möhn

Larva with the inner incision of spatula shallow (Fig. 6E); leaf galls on Trixidis radialis (L.) Kuntze (Distrib. El Salvador: La Libertad, NE Sitio del Nino).......... A. trixidis Möhn

12. Larva with three inner and two outer lateral papillae; stem galls on Calea zacatechichi Schltdl. (Distrib. El Salvador: San Vicente, SE Santo Domingo, km 54) ... zacatechichi Möhn

- Larva with one or two inner and two outer lateral papillae. 13

13. Larva with two inner and two outer lateral papillae; two pairs of setose terminal papillae of larva (Fig. 8B); bud galls on Lepidaploa canescens (Kunth) $\mathrm{H}$. Rob. (Distr. El Salvador: La Libertad, Los Chorros).... A. ajallai Möhn

- Larva with one inner and two outer lateral papillae, larva with another arrangement of terminal papillae. ... 14

14. Larva with one pair of setose terminal papillae (Fig. 5B); pupa with lower frontal horn trilobed; stem and petiole galls on Lessingianthus warmingianus (Baker) H. Rob. (Distrib. Brazil: Minas Gerais, Santana do Riacho) A. cipo sp. nov. Urso-Guimarães

- L Larva with three (Fig. 8D) or four pairs of terminal papillae (Fig. 8E); pupa with lower frontal horn absent or one-lobed 15

15. Larva with three pairs of corniform terminal papillae (Fig. 8D); pupa with lower frontal horn one-lobed; leaf galls on Mikania sp. (Distrib. Brazil: Rio de Janeiro, Palmeiras). A. ulei Rübsaamen

Larva with four pairs of terminal papillae, three setose and one corniform (Fig. 8E); pupa with lower frontal horn absent; leaf galls on Eremanthus erythropappus (DC.) MacLeish (Distrib. Brazil: Minas Gerais, Tiradentes, Serra de São José) A. serrata Maia

\section{ACKNOWLEDGMENTS}

The author acknowledges support from FAPESP (Proc. \#99/01429-1), Dr. Carlos J.E. Lamas for providing access to the facilities at MZUSP, Dr. Marcelo Monge Egea (IB/UNICAMP) for identifying the host plant species, Dr. Adolfo R. Calor (UFBA), Dr. Sidnei Matheus (FFCLRP/USP), and Dr. Charles M.D. dos Santos (UFABC) for collaboration in the field work; and Dr. Raymond J. Gagné for commenting on a draft version of the manuscript.

\section{REFERENCES}

Antar, G.M. \& Loeuille, B. 2015. Contribution to the Vernonieae (Asteraceae) of the Cerrado: a transfer to Lessingianthus, in a new rank and with a new name. Phytotaxa, 238(1): 082-091.

Carneiro, M.A.A.; Borges, R.A.X.; Araújo, A.P.A. \& Fernandes, G.W. 2009. Insetos indutores de galhas da porção sul da Cadeia do Espinhaço, Minas Gerais, Brasil. Revista Brasileira de Entomologia, 53(4): 570-592.

Coelho, M. S.; Carneiro, M. A.A.; Branco, C. A. \& Fernandes, G. W. 2013. Gall-inducing insects from Serra do Cabral, Minas Gerais, Brazil. Biota Neotropica, 13(3): 102-109. DOI

Dematteis, M. \& Almeida, G. 2015. Lessingianthus. In: Reflora. Flora do Brasil 2020 - Algas, Fungos e Plantas. [under construction]. Jardim Botânico do Rio de Janeiro. Available from: http://floradobrasil.jbri.gov.br/reflora/ floradobrasil/FB27237. Access in: 15/05/2018.

Flor, I.C. \& Maia, V.C. 2017. Representativity of the genus Asphondylia Loew, 1850 (Diptera, Cecidomyiidae) in Brazil. Papéis Avulsos de Zoologia, 57(30): 393-404. D0l. Access in: 15/05/2018.
Gagné, R.J. 1994. The Gall Midges of the Neotropical Region. Ithaca, Cornell University Press. XV, 352p.

Gagné, R.J. \& Jaschhof, M. 2017. A catalog of the Cecidomyiidae (Diptera) of the world. 4. ed. Digital, 762 pp. Available online: https://www.ars.usda. gov/ARSUserFiles/80420580/Gagne 2017 World Cat 4th ed.pdf. Access in: 02/07/2018.

Gagné, R.J.; Oda, R.A.M. \& Monteiro, R.E. 2001. The gall midges (Diptera: (ecidomyiidae) of Mikania glomerata (Asteraceae) in Southeastern Brazil. Proceedings of the Entomological Society of Washington, 103: 110-134.

Karsch, F. 1877. Revision der Gallmücken. Münster, E.C. Brunn. 58p., 1 pl.

Kieffer, J.J. \& Herbst, P. 1905. Uber Gallen und Gallenerzeuger aus Chile. Zeitschrift für wissenschaftliche Insektenbiologie, 1: 63-66.

Loew, H. 1850. Dipterologische Beiträge. IV. Posen, 40p, 1 pl.

Maia, V.C. 2004. A new genus and six new species of gall midges (Diptera, (ecidomyiidae) from Serra de São José (Minas Gerais State), Brazil). Arquivos do Museu Nacional, 62: 69-82.

Maia, V.C. 2012. Coleopterous galls from the Neotropical region. Papéis Avulsos de Zoologia, 52(15):175-184. DOI

Möhn, E. 1959. Gallmücken (Diptera, Itonididae) aus El Salvador. 1. Teil. Senckenbergiana Biologica, 40: 297-368.

Möhn, E. 1960. Gallmücken (Diptera, Itonididae) aus El Salvador. 2. Teil. Senckenbergiana Biologica, 41: 197-240.

Möhn, E. 1973. Studien über neotropische Gallmücken (Diptera, Itonididae). 2. Teil. Stuttgarter Beiträge zur Naturkunde, 257: 1-9.

Rübsaamen, E.H. 1908. Beiträge zur Kenntnis aussereuropäischer Zoocecidien. III. Beitrag: Gallen aus Brasilien und Peru. Marcellia, 6: 110-173.

Wünsch, A. 1979. Gallenerzeugende Insekten nordkolumbiens, speziell Asphondyliidi und Lasiopteridi (Diptera, Cecidomyiidae) aus dem Küstenbereich um Santa Marta. Wünsch, Ludwigsburg-Hoheneck, 238p. 